\title{
Reconceptualising the Child's Right to Development: Children and the Capability Approach
}

\author{
Noam Peleg \\ University College London, UK \\ n.peleg@ucl.ac.uk
}

\begin{abstract}
The article proposes adopting the Capability Approach as a theoretical framework to analyse the child's right to development. Currently, the child's right to development is realised as the child's right to become an adult. This interpretation is problematic on several grounds, primarily its usage of developmental psychology as an underlying narrative to conceptualise childhood and interpret children's rights, and its lack of respect for children's agency. Using the Capability Approach's conception of 'human development' as an alternative framework can change the way in which childhood and children's development are conceptualised and, consequently, change the interpretation of the child's right to development. It can accommodate simultaneously care for the child's future and the child's life at the present; promote respect for a child's agency and active participation in her own growth; and lay the foundations for developing concrete measures of implementation.
\end{abstract}

Keywords

children's rights; right to development; capability approach; childhood studies; UN Convention on the Rights of the Child

\section{Introduction}

The UN Convention on the Rights of the Child provides broad protection for children's development. Five articles (Articles 18, 23, 27, 29 and 32) protect eight domains of development (physical, mental, moral, social, cultural, spiritual, personality and talent), and a sixth, Article 6, protects the child's right to life, right to survival and right to development. Nonetheless, it is not clear

\footnotetext{
* The author would like to thank Michael Freeman and Aoife Nolan for their helpful comments. An earlier version of this article was presented at the ESRAN-UKI seminar held in University College Dublin in May 2013. The author would like to thank the participants of this seminar for their feedback. Special thanks to Lana Tatour. Any errors are his.
} 
enough what are the theoretical or practical implications of providing children with the legal right to development. This article suggests that the first stage in interpreting this unique right of children is to establish the meaning or meanings of the terms 'children's development' and childhood. Only then will it be possible to discuss what it means for children to have a right to development.

The term 'children's development' is usually perceived in psycho-social terms, focusing on the process of transformation from childhood to adulthood. Such conceptualising of 'children's development' resonates with the conception of children as 'human becomings,', and leads to a narrow interpretation of the child's legal right to development, primarily as the child's right to become an adult. This approach subjugates the right to development to support the child's future, thus overlooking other meanings of childhood and ignores children's agency. As the jurisprudence of the UN Committee on the Rights of the Child demonstrates, ${ }^{2}$ this approach also lacks coherency and creates serious difficulties in implementation. The core argument of this article is that changing the definition of 'children's development' can result in reconceptualising the child's right to development as well.

The article suggests that adopting the Capability Approach as an alternative normative framework can remedy these shortcomings in the current understanding of the child's right to development. Adopting the perception of human development as 'freedom' 3 can redefine the meaning of 'children's development' in a way that includes not only the child's developmental psychology, but also the child's entitlement to define the course of her life; to respect the child's life in the present; to respect the child's agency and voice; and to lay the foundations for concrete measures of implementation.

Thus far, the discussions concerning the Capability Approach have largely ignored children, ${ }^{4}$ which left it 'under-theorized in relation to children', ${ }^{5}$ and children's rights. It was only recently that Martha Nussbaum and Rosalind Dixon have addressed the relationship between children and the Capability Approach, arguing that the Capability Approach can be used as a theoretical

\footnotetext{
1) James, A. et al, Theorizing Childhood (Cambridge: Polity, 1998); James, A. and A. James, Constructing Childhood (Basingstoke: Palgrave Macmillan, 2004); Lee, N., Childhood and Society (Gosport: Open University Press, 2001); James, A. and A. Prout, 'Re-presenting Childhood: Time and Transition in the Study of Childhood' in Constructing and Reconstructing Childhood. James, A. and A. Prout, eds. (2nd edition, London: Routledge, 1997) 230-250; Freeman, M.,'The Human Rights of Children' Current Legal Problems 63 (2010): 1-44.

2) Peleg, N., 'Time to Grow Up: The UN Committee on the Rights of the Child's Jurisprudence of the Right to Development' in Law and Childhood Studies. Freeman, M., ed. (Oxford: Oxford University Press, 2012) 371-391.

3) Sen, A., Development as Freedom (Oxford: Oxford University Press, 1999).

4) Comim, F. et al, 'Introduction - Theoretical Foundations and the Book's Roadmap' in Children and the Capability Approach. Mario Biggeri et al, eds. (Basingstoke: Palgrave, 2011) 3-21, 6.

5) Basu, K., 'Prologue' in Children and the Capability Approach, ibid, $\mathrm{x}$.
} 
justification for prioritising children's welfare rights. ${ }^{6}$ Their paper will be discussed in detail later, but it is important to note at this stage that their argument does not address broader questions relating to children's rights, including the child's right to development.

It is beyond the scope of this article to exhaust all the questions that the relationship between the Capability Approach and children's rights raises. Rather, the article will focus on two main questions: whether the Capability Approach's conception of development should be used in analysing the child's right to development, and if the answer is in the affirmative, how it should be done.

The article has four parts. The first introduces briefly the Convention's conception of 'children's development' and right to development, as was interpreted by the UN Committee on the Rights of the Child. It claims that the Committee adopts a 'human becomings' conception of childhood, and therefore its interpretation focuses on the child's life as an adult, thus failing to respect children's agency and voice. Such an interpretation for a core right is somewhat problematic, since it neither provides coherent meaning, nor a concrete means of implementation. The second part introduces the Capability Approach's conception of human development and suggests that it can, and should, be used in interpreting children's development. The third part explores the possibilities of using the Capability Approach when interpreting human rights law, and discusses the potential limitations and advantages of this approach. The fourth and last part delineates three main contributions of the suggested approached: redefining the term 'children's development'; enhancing respect for children's agency and voice; and developing concrete benchmarks to realise the right to development according to the UNCRC's framework.

\section{The current approach to the child's right to development}

As noted earlier, the UNCRC provides comprehensive protection for eight different segments of children's development, which join the recognition of children's rights to development in Article 6(2). The importance that the Convention sees in protecting children's development was further emphasised by the UN Committee on the Rights of the Child in General Comment Number 5, which defines the rights to life, survival and development as one of the Convention's four guiding principles, together with the child's right to non-discrimination (Article 2), the child's right to participation (Article 12) and the principle of the best interests of the child (Article 3$) \cdot{ }^{7}$ Furthermore, in

6) Dixon, R. and M. Nussbaum, 'Children's Rights and a Capability Approach: The Question of Special Priority' Cornell Law Review 97 (2011-2012): 549-593.

7) UNCRC, General Comment number 5, CRC/GC/2003/5. 
its guidelines for reporting, the Committee asks States Parties to report on measures taken to ensure children's right to development. ${ }^{8}$ Nonetheless, the Committee's jurisprudence demonstrates how difficult it is to interpret the right when your point of departure is the 'human becomings' conception of childhood. ${ }^{9}$

The 'human becomings' conception of childhood perceives children as passive actors, lacking agency, weak, vulnerable, and in need of protection. ${ }^{10}$ Childhood and children are positioned against adulthood and adults, and childhood is described as 'the absence of adult qualities."11 Children are seen as 'unfinished products', 12 and as human beings in the making. Childhood is therefore a 'journey toward a destination', ${ }^{13}$ or as James and Prout articulate it, childhood is 'a highly complex and engineered trajectory towards adulthood'. ${ }^{14}$ In a similar vein, children's development has been cared for according to mainstream developmental psychology theories. Using developmental psychology perpetuates the image of the child as a person that ought to 'successfully' or 'normally' climb up the ladder of development, and eventually completes the transition and becomes a fully competent adult. However, developmental psychology, as Erica Burman notes, is neither a homogeneous body of knowledge, nor a neutral one. It creates a specific image of childhood that ultimately enables adults to colonise children and control their lives. ${ }^{15}$

Therefore, when the 'human becomings' conception of childhood is used in conjunction with developmental psychology, it is almost impossible to interpret the right to development in any way other than as a right of the child to become an adult. While circumventing from defining the right to development itself, the Committee prioritises the protection of children's development in one of two ways: it either defines it as a violation of one right of the child, for example the right to education (Articles 28-29) as a violation of the right to development as well, or it determines that a protection of another and

8) UNCRC, Treaty-specific guidelines regarding the form and content of periodic reports to be submitted by States parties under article 44, paragraph $1(b)$, of the Convention on the Rights of the Child, CRC/C/58/Rev.2.

9) Peleg, supra n. 2. See also Martin Woodhead's claim that only young children are entitled to this right. M. Woodhead, 'Early Childhood Development: A Question of Rights', International Journal of Early Childhood 37 (2005): 79-98.

10) For non-Western perspectives see, for example, Stafford, C., The Roads of Chinese Childhood (Cambridge: Cambridge University Press, 1995); Ito, T., 'New Education For Underprivileged Children: The Condition of Children's Rights in Japanese Law', Paedagogica Historica 48 (2012): 153-167. See also LeVine, R.A. and R. S. New, Anthropology and Child Development (Oxford: Blackwell Publishing, 2008).

11) Archard, D., Children: Rights and Childhood (London: Routledge, 1993) 36.

12) Smart, C. et al, The Changing Experience of Childhood (Cambridge: Polity, 2001) 1.

13) Lee, supra n. $1,8$.

14) James and Prout, supra n. 1, 226.

15) Burman, E., Deconstructing Development Psychology (2nd edition, Palgrave: London, 2008). 
different right, for example the right to non-discrimination (Article 2), is a precondition for the realisation of the child's development (and rarely also the right to development). ${ }^{16}$ This approach fails to respect children's agency in the context of development, and thus perpetuates the image of the child as an adult in making. It also does not provide a distinct or a coherent meaning to the right to development, which makes it difficult to implement.

In contrast to the 'human becomings' conception, the 'human beings' conception ${ }^{17}$ embraces diverse and more complex notions of childhood. ${ }^{18}$ According to this approach, children are perceived as active persons and not as 'projects', 19 and childhood is being studied independently, and not by comparing children to adults. ${ }^{20}$ As human 'beings', children are considered as human rights holders, ${ }^{21}$ which means that they 'can exercise agency... as agents, rights bearers can participate. They can make their own lives, rather than having their lives made for them. ${ }^{22}$ As social agents, ${ }^{23}$ children can now be seen as part of the social structure and social fabric, and subsequently their active role in it is respected. ${ }^{24}$ This respect includes having their opinions heard and taken into consideration. Article 12 of the Convention reflects this perception in acknowledging the child's right to participation. ${ }^{25}$

When one listens to children, one realises just how much children know about their lives and about their world. Children make sense of their own experience of poverty (and what qualifies as 'well-being'), ${ }^{26}$ of living on the

16) Peleg, supra n. 2.

17) Wells, K., Childhood in a Global Perspective (Cambridge: Polity Press, 2009) 1-24.

18) Prout, A., The Future Of Childhood (London: Routledge, 2005) 7-34; Prout and James, 'A New Paradigm for the Sociology of Childhood? Provenance, Promise and Problems' in James and Prout, supra n. 1, 7-33.

19) Smart et al, supra n. 12, 13 .

20) James and Prout, supra n. 1, 8. See also Mayall, B., Towards a Sociology of Childhood: Thinking From Children's Lives (Gosport: Open University Press, 2002) 33.

21) Freeman, M., The Moral Status of Children (The Hague: Martinus Nijhoff, 1997). But see Annette Ruth Appell's claim that even so, children's rights are still being measured against their dependency. Ruth Appell, A., 'The Pre-Political Child of Child-Centered Jurisprudence' Houston Law Review 46 (2009-2010): 703-757, 721.

22) Freeman, M., 'Why It Remains Important to Take Children's Rights Seriously', International Journal of Children's Rights 15 (2007): 5-23, 8.

23) James, Allison, 'Agency', in Palgrave Handbook of Childhood Studies. Qvortrup, J. et al, eds. (Basingstoke: Palgrave 2009, 2011) 45-54.

24) Ibid, 38-40.

25) For an analysis of Article 12, see L. Lundy, "Voice” is Not Enough: Conceptualising Article 12 of the UN Convention on the Rights of the Child', British Educational Research Journal (2007) 33: 927-942.

26) Camfield, L. et al, 'What's the Use of "Well-Being" in Contexts of Child Poverty? Approaches to Research, Monitoring and Children's Participation' International Journal of Children's Rights (2009) 17: 65-109; Goswami, H., 'Social Relationships and Children's Subjective Well-Being' Social Indicator Research, (2011) Online First 26.5.2011; Z. Pavlovic and T. R. Leban, 'Children's Rights International Study Project (CRISP) - A Shift from the Focus on Children's Rights to a Quality of Life Assessment Instrument' Child Indicators Research 2 (2009): 265. 
street, ${ }^{27}$ of their health or from the fact that there are dying. ${ }^{28}$ Children are also able to articulate what human rights means, ${ }^{29}$ and how the UNCRC can be interpreted. ${ }^{30}$ If listened to, children can express their own point of view about their own development. Research shows that children are able to distinguish between the progression of development and the aims it should achieve. They associate 'development' with having a sense of direction in life, and what they see as the natural process of maturation. When perceiving 'development' as a natural process, according to Helga Kelle, the notion of getting older 'can hardly be seen as a personal achievement'. ${ }^{31}$ As Priscilla Alderson et al have shown, ${ }^{32}$ children's ability to express their views and preferences is not necessarily a matter of age, but of space and willingness of adults to listen to them as well. Needless to say, it is not always easy to facilitate children's participation (and decision-making), ${ }^{33}$ but problems in implementation should not undermine the foundations of the principle and its pursuit. If we respect children's agency and autonomy, we also need to respect their values and priorities. ${ }^{34}$

Such an approach towards childhood and children's development is radically different from the one that is used today. The alleged paradigm shift in childhood studies has skipped the discussion concerning 'children's development' and right to development. The image of the developing child still dominates and dictates the discussion about this right. For this reason, for example, the right to development is usually overlooked in the literature, even when

27) Mandel Butler, U., 'Freedom, Revolt and "Citizenship"', Childhood 16 (2009): 11-29; See also Raffaelli, M., 'How Do Brazilian Street Youth Experience "the Street"?', Childhood 8 (2001) 396-415.

28) Bluebond-Langner, M., The Private Worlds of Dying Children (Princeton: Princeton University Press, 1978) 5.

29) Ruck, M. D. et al, 'Children's and Adolescents' Understanding of Rights: Balancing Nurturance and Self-Determination', Child Development 64 (1988): 404; Ruck, M. D. et al, 'Adolescents' and Children's Knowledge About Their Rights: Some Evidence For How Young People View Rights In Their Own Lives' Journal of Adolescence 21 (1998): 275-289.

30) Heesterman, W.'An Assessment of the Impact of Youth Submission on the United Nations Committee on the Rights of the Child', International Journal of Children's Rights 13 (2005): $351-378$.

31) Kelle, H., "The Discourse of "Development" - How 9 to 12-Year-Old Children Construct "Childish" and "Future Development" Identified Within Their Peer Culture', Childhood 8 (2001): 95-111, 109; In a different context see Maclure, R., 'The Dynamics of Youth Participation: Insights from Research Fieldwork with Female Youth in Senegal', in Children's Rights and International Development. Denov, M. et al, eds. (New York, Palgrave, 2011) 155-174.

32) Alderson, P. et al, 'The Participation Rights of Premature Babies', International Journal of Children's Rights 13 (2005): 31-50.

33) Holland, S. et al, 'Power, Agency and Participatory Agenda: A Critical Exploration of Young's People's Engagement in Participative Qualitative Research', Childhood 17 (2010): 36o-375.

34) Ballet, J. et al, 'Children Agency and the Capability Approach - A Conceptual Framework' in Children and the Capability Approach. M. Biggeri et al, eds. (Basingstoke: Palgrave Macmillan 2011) 22-46, 22. 
discussing the connection between law and child development, ${ }^{35}$ or international development and children. ${ }^{36}$

In the next section I argue that using the Capability Approach as a theoretical framework can lead to a reconceptualisation of 'children's development', and subsequently the child's right to development, in a way that can offer a remedy to these shortcomings.

\section{The capability approach's concept of 'human development'}

The Capability Approach (or 'approaches') ${ }^{37}$ is a moral theory that focuses on human development, suggesting that 'development' should be conceptualised as 'freedom'. ${ }^{38}$ The Capability Approach is a response to the traditional approach, which linked human development to economic growth as a means of eliminating poverty and satisfying people's 'basic needs'. ${ }^{39}$ Amartya Sen and Martha Nussbaum, who pioneered this theory, claimed that the traditional conception of human development reflects a narrow understanding of human life and poverty, and is blind to social exclusion. Ignoring those at the margins, Sen and Nussbaum argue, is being disrespectful of people's human dignity. They therefore suggested conceptualising 'development' as a process that facilitates people's ability to live lives worth living, ${ }^{40}$ by expanding their capability and increasing their real opportunities. Taking the view that people should not be bound by choices determined by others, ${ }^{41}$ they claim that people should have a stake in shaping their own lives in a way that respects their agency. ${ }^{42}$

Arguably, the best way to realise those personal preferences is by respecting people agency and participation in making choices. Participation should not

\footnotetext{
35) See, for example, Buss, E. and M. Maclean, The Law and Child Development (Falmer: Ashgate, 2011), and Freeman, F., 'Emily Buss and Mavis Maclean - The Law and Child Development', International Journal of Children's Rights 19 (2011): 705-707, 707.

36) Hanson, O. and O. Nieuwenhuys, Reconceptualizing Children's Development in International Development (Cambridge: Cambridge University Press, 2013).

37) It has also been suggested that it should be called 'the capability creation'. Gasper, D., 'What Is the Capability Approach? Its Core, Rationale, Partners and Dangers', Journal of SocioEconomics 36 (2007): 335-359, 346.

38) Sen, supra n. 3.

39) Esteva, G., 'Development' in The Development Dictionary. W. Sachs, ed. (London: Zed Books, 1992) 6-25; Streeten, P. and S. Javed Burki, 'Basic Needs: Some Issues' World Development 6 (1978): 411-421; On women's basic needs see I. Palmer, 'Rural Women and the Basic Needs Approach to Development', International Labour Review 115 (1977): 97-107.

40) Moore, A. and R. Crisp, 'Welfarism in Moral Theory', Australian Journal of Philosophy 74 (1996): 598-613; L. Hamilton, 'A Theory of True Interests in the Work of Amartya Sen', Government and Opposition 34 (1999): 516.

41) Sen, A., Inequality Re-examined (Cambridge: Harvard University Press, 1992) 39.

42) Dixon and Nussbaum, supra n. 6, 557.
} 
be seen only as a methodological tool, but also as a substantial element of development. Participation guarantees people's freedoms and 'enhances the ability of people to help themselves and also to influence the world... the concern here relates to what we may call the "agency aspect" of the individual: ${ }^{43}$ According to Nussbaum, denying people the ability to choose not only denies their agency but also 'makes life not worthy of human dignity'.44 According to Sen, freedom to choose is 'both the primary end' and 'the principal means of development. ${ }^{45}$ I therefore argue that utilising this approach to human development in the context of children's rights in general, and of the right to development in particular, can radically change the way this right is addressed, and gives it a new necessary meaning.

If development is freedom, then 'unfreedom' is a deprivation of capabilities. For example, unfreedom can be a situation of famine or being under nourished, or having limited access to social services such as health care or functional education. In more abstract terms, Sen suggests that 'unfreedom' should be defined as an inequality 'between women and men [and] denial of political liberty and basic civil rights' ${ }^{\prime 6}$ Social, political, economic and cultural power structures constitute the core causes of unfreedoms, since they prevent the marginalised from benefiting from economic prosperity. Arguably, children are structurally positioned in most societies in a chronic condition of 'unfreedon' due to political, social and cultural structures and social attitudes towards children.

Another assertion is that people should not be seen as homogenous or as having equal opportunities. Gender, disability, age, ethnicity or illness have great influence on levels of income and accessibility to social services, which are necessary to maintain similar standards of living. For example, a person with a disability needs to spend a larger percentage of her income on buying medications and treatments (and also needs more access to health care services) than what a person without a disability and a same level of income spends on her health. Therefore, in order to maintain a similar standard of living, these two peoples need different resources. I argue that this analogy applies to children as well. Children should not be seen as a homogenous group, and their unique requirements for living dignified lives ought to be met. ${ }^{47} \mathrm{~A}$ similar conclusion should be reached when taking the approach the agency of every child should be respected. In the context of their right to

\footnotetext{
43) Ibid.

44) Nussbaum, M. C., Creating Capabilities - The Human Development Approach (Cambridge: Harvard University Press, 2011) 31.

45) Ibid, 16.

46) Ibid, 15 .

47) Cf to Dixon and Nussbaum, supra n. 6, 556-563.
} 
development, contextualising children's lives based on social attitudes toward their individual characteristics (gender, disability etc.) or their group affiliation (social class, religious etc.) will enable to diversify the meaning of children's development accordingly.

Another significant dimension of the Capability Approach is the idea of 'functions'. According to Sen, functions are 'the various things a person may value being and doing' ${ }^{48}$ This includes, for example, having a job or being healthy, as well as more abstract concepts such as happiness. Sen argues that every person should define his or her own functions, and therefore he does not suggest one definitive set of functions. ${ }^{49}$ Nonetheless, a precondition to be able to define a set of personal functions and being able to live accordingly, is having necessary capabilities. Sen uses the availability of food as an example to illustrate his point about the connection between functions and capabilities. According to this example, a person might not eat for one of two reasons: either he does not have food, or he has decided to fast or go on a diet. ${ }^{50}$ While the latter is a matter of choice (function), the former is a matter of lack of capabilities. Capabilities can therefore be understood as 'the range of options a person has in deciding what kind of life to lead', ${ }^{51}$ which 'represent the various combinations of functioning (being and doing) that the person can achieve, ${ }^{52}$ and as such constitutes one's freedom. Nussbaum defines capabilities in slightly different terms, claiming that capabilities are those entities that enable people to execute their human functions. ${ }^{53}$ Capabilities should therefore be understood as 'what people are actually able to do and to be. ${ }^{54}$ According to Nussbaum, all human beings ought to have the freedom to choose whether they exercise these capabilities and in which ways they do so. ${ }^{55}$ Despite the tendency to overlook children in that regard, children too should be seen as entitled to exercise their agency and capabilities. While doing so, it is up to the duty bearers - in the context of the UNCRC they are the child's parents (or other legal guardians), the state and the international community ${ }^{56}$ - to enable them to do so. This position is similar, but not

48) Sen, Development as Freedom, supra n. 3, 75.

49) Sen, A., 'Human Rights and Capabilities' Journal of Human Development 6 (2005): 151, 157-16o.

50) Sen, Inequality Re-examined, supra n. 41.

51) Drèze, J. and A. Sen, India: Economic Development and Social Opportunity (Oxford: Oxford University Press, 1995) 10.

52) Sen, Inequality Re-examined, supra n. 41, 4.

53) M. Nussbaum, M., 'Women's Capabilities and Social Justice', Journal of Human Development 1 (2000): 219-247, 242.

54) Ibid, 222-223.

55) Ibid, 235.

56) Article 4 of the UNCRC. 
identical, to the positions of John Holt and Richard Farson, ${ }^{57}$ not least because it is not a call for neglecting children to their rights. ${ }^{58}$ Instead it argues for change in the theoretical approach towards children's development and their a bility - and rights - to exercise agency and participate in shaping their own lives.

Distinguishing between internal capabilities and substantial freedoms helps to realise the differences between 'freedom' and 'capabilities'. Internal capabilities are a person's intellectual and emotional capacities, fitness and health, level of learning skills etc. Substantial freedom is the ability to make a choice. This ability depends on personal capacities as well as the political, social and economic environments as combined capabilities. Based on this distinction, Nussbaum argues that if a given society seeks to promote human capabilities, it ought to support the development of internal capabilities 'through education resources to enhance physical and emotional health, support for family care and love, a system of education and much more. ${ }^{59}$ This distinction clarifies how society can enable the production of internal capabilities, while reducing or eliminating the options of people to function in accordance with those capabilities. For example, people can be given access to education in order to develop their capability to express themselves. But if soon after they are denied the right to freedom of expression, for example, their combined capability is denied as well. ${ }^{60}$ Society, therefore, cannot provide and produce combined capabilities 'without producing internal capabilities' ${ }^{61}$ This distinction, and call for holistic and continuing securing capabilities, ${ }^{62}$ is vital for children and important for the reconceptualisation of the child's right to development, as the next section elaborates.

\section{The capability approach and the child's right to development}

This section develops the argument that children should be seen as entitled to develop, according to the Capability Approach's conception of human development. I suggest that to reconceptualise the meaning of 'children's development' according to the Capability Approach can change the interpretation of the child's right to development. More specifically, it can enhance further

\footnotetext{
57) Holt, J., Escape From Childhood (Middlesex: Penguin Books, 1974); Farson, R. E., Birthrights (Michigan: University of Michigan Press, 1974).

58) Cf to Hafen, B. C. and J. O. Hafen, 'Abandoning Children to Their Autonomy: The United Nations Convention on the Rights of the Child', Harvard International Law Journal (1996) 37: 449-492.

59) Nussbaum, Creating Capabilities - The Human Development Approach, supra n. 44, 21.

60) Ibid, 23 .

61) Ibid.

62) Wollf, J. and A. De-Shalit, Disadvantage (Oxford: Oxford University Press, 2007).
} 
respect for children's agency and voice, and it will make it possible to concretise the meaning of the child's right to development. But first, there is a need to address the preliminary questions concerning the ability to adapt the Capability Approach to interpret children's human rights. After answering this question in the affirmative, I will discuss the nexus between the Capability Approach and children.

As has been mentioned earlier, until recently the applicability of the Capability Approach to children has rarely been addressed, and only recently have these questions begun to attract some attention. ${ }^{63}$ One of the main reasons for this lack of discussion is rooted, I believe, in Sen upholding the 'human becomings' model of childhood, suggesting that children will enjoy their freedoms when they become competent adults. ${ }^{64}$ Competency is therefore a key difficulty that Sen sees in linking children and the Capability Approach. Madoka Saito expresses a similar concern, when he asks, 'how can we apply the Capability Approach to children, since children are not mature enough to make decision by themselves?'65 Likewise, Biggeri et al assert that the 'Capability Approach obviously implies the individual's capacity for self-determination, which may not apply to children'.66

The question of children's competence and capacity to choose is not unique to this context. The question, or the tension, about the relationship between capability and capacities is being asked about almost every aspect of the child's life and rights, including, for example, consent to medical treatment, ${ }^{67}$ the age of criminal responsibility ${ }^{68}$ and the right of children to vote in a country's general election. ${ }^{69}$ These debates are relevant in our context as they demonstrate the dominance of conceptions about children's capacities, thus demonstrating that this is a normative debate rather than a question of having 'empirical' capacities to choose. In other words, it is not children's ability to choose that is debated, but rather the space that society, adults and the law gives children

63) See, for example, the collection of articles by Biggeri et al, supra $n$. 4. See also Hanson and Nieuwenhuys, supra n. 36 .

64) Saito, M., 'Amartya Sen's Capability Approach to Education: A Critical Exploration', Journal of Philosophy of Education 37 (2003): 17, 25.

65) Saito, Supra n. 64.

66) Biggeri, M. et al, 'Children's Agency and the Capability Approach: A Conceptual Framework', supra n. 4, 22-45, 24.

67) A leading case is Gillickv. West Norfolk and Wisbech Area Health Authority [1986] AC 112. See Freeman, M., 'Rethinking Gillick', International Journal of Children's Rights 13 (2005): 201-217.

68) Different countries subscribe to different age of criminal responsibility, ranging from the age of 7 to the age of 18 . See Melchiorre, A. and E. Atkins, At What Age Are School-Children Employed, Married and Taken to Court? (Right to Education Project, London 2011) 30-32.

69) Jans, M., 'Children as Citizens', Childhood 11 (2004): 27-44; Wall, J., 'Can Democracy Represent Children? Towards a Politics of Difference', Childhood 19 (2012): 86-100; Roche, J., 'Children: Rights, Participation and Citizenship', Childhood 6 (1999): 475-493; Nolan, A., Children's Socio-Economic Rights, Democracy and the Courts (Oxford: Hart, 2011) 43-92. 
in order to make a choice, and the tolerance for what adults consider to be a mistake.

The issue here is not empirical but normative: whether society and adults, who dominate children's lives, respect children's right to choose and to develop, and if so - to what extent. I therefore suggest that the Capability Approach should be acknowledged as relevant to children for all the reasons that it is considered to be relevant to all human beings, including the elderly and those with disabilities (while acknowledging the fundamental differences between children and these two groups). ${ }^{70}$ Claiming that the Capability Approach is not relevant to children because children lack the capacity to choose undermines the core principle of the Capability Approach itself. One cannot advocate in favour of respecting the human dignity and agency of all people, especially those who formerly were at the margins of their societies (and were perceived to lack certain capacities), while denying the same universal principles from children, by arguing that they lack capacities. Furthermore, the proposition that children lack required capacity is a selffulfilling prophecy, leading to a situation where children are being denied the opportunity to challenge this presumption, thus perpetuating the denial of their agency. ${ }^{71}$ This approach creates a vicious circle that excludes children from the ability to develop, according to the Capability Approach's conception of development as freedom.

Following Nussbaum's discussion about internal and combined capabilities, it can be further argued that once children are given the opportunity to develop their internal capabilities, primarily through education, they will no longer be denied the opportunity or entitlement to develop. This statement can be formulated in human rights terms, thus suggesting that children can develop their internal capabilities when their human right to education is being realised, and their agency is respected. At this point it becomes evident that respecting children's agency and rights is an issue that keeps reappearing in considering any aspect of the child's right to development. Therefore, I will now discuss the applicability of utilising the Capability Approach to analyse human rights law.

\section{Human rights law and the capability approach}

Sen distinguished between the ethics of human rights and human rights law, claiming that the moral strength of the former does not require the existence

\footnotetext{
70) Cf to Dixon and Nussbaum, supra n. 6.

71) On this see Federle, K. H.,'Rights Flow Downhill', International Journal of Children's Rights 2 (1994): 343-368.
} 
of the latter. At a practical level, Sen claims that human rights law is a good rhetorical tool for creating and imposing obligations on states to provide the capabilities necessary for human development. ${ }^{72}$ Referring to the structure of international human rights law, Séverine Deneulim asserts that the Capability Approach enables us to look at the institutional framework that allows that right to be fulfilled. ${ }^{73}$ In other words, the Capability Approach can be seen as 'an evaluative framework for assessing states of affairs.' ${ }^{74}$ According to this approach, human rights analysis defines social structures according to the Capability Approach, but should not follow it in interpreting specific rights. Unlike Sen, Nussbaum is much more in favour of connecting the Capability Approach and human rights, including children's rights. ${ }^{75}$

A different question is concerned with equality and discrimination. While the recognition of diversity among people and the impacts that disadvantages have on people's development is central to the Capability Approach, Deneulim claims that 'the human rights approach does not necessarily take such differences into account, ${ }^{76}$ and therefore will not fulfil the Capability Approach's goals. The problem with this liberal argument is that it ignores substantial equality and affirmative action policies. It is against this approach that Dixon and Nussbaum claim that the Capability Approach can be used in order to justify prioritising children's welfare rights, ${ }^{77}$ especially those rights that are sensitive 'both to children's welfare needs and to children's agency' ${ }^{\prime 8}$ However, in their discussions, Dixon and Nussbaum compare children's competence, agency and rights to the rights of people with intellectual disabilities, claiming that recognition of children's rights is based on a similar 'moral claim of all human beings to be afforded full human dignity, regardless of their capacity for rational or reasoned participation in public or civil life. ${ }^{79}$ Therefore, children's 'vulnerability'80 justifies affirmative action policies, which aim to provide children with the necessary capabilities to be free.

\footnotetext{
72) Sen, A.,'Capabilities and Well-Being' in Quality of Life. Nussbaum, M. and A. Sen, eds. (Oxford: Oxford University Press, 1993) 30-53.

73) Deneulim, S., 'Ideas Related to Human Development' in An Introduction to the Human Development and Capabilities Approach. Deneulim, S. and L. Shahani, eds. (London: Earthscan, 2009) 49-70, 6 o.

74) Ibid.

75) Nussbaum, M., 'Human Capabilities, Female Human Beings' in Women, Culture and Development: A Study on Human Capabilities. M. Nussbaum and J. Glover, eds. (Oxford: Oxford University Press, 1995) 61-104; Nussbaum, M., 'Capabilities as Fundamental Entitlements: Sen and Global Justice', Feminist Economics 9 (2003): 33-59.

76) Ibid, 61.

77) Dixon and Nussbaum, supra n. 6.

78) Ibid, 553 .

79) Ibid.

80) Ibid, $573-578$. The second justification is 'cost effective analysis'; see pp. 578-584.
} 
Such a comparison is highly problematic for a number of reasons. First, it measures children against adult-tailored standards of competency, perpetuating the notion that a competent adult is the standard that children must meet in order to be entitled to develop. Second, it refutes the respect we have for children for what they will become ('human becomings') or for who they are now ('human beings'). Third, it contradicts the perceptions of children as 'human becomings' and as persons in a mode of change and developing their capacities. While children are 'developing' and are capable of change, adults with intellectual disabilities are in a static mode. They do not develop and their capacities, by and large, do not evolve. Fourth, this comparison implies that childhood is some sort of disability. While there may be some similarities between the current cognitive functions of children and adults with mental capabilities, placing them in the same category not only undermines respect for children's human dignity in general, but also raises the question of how children with mental capabilities should be conceptualised, and how they should be treated in light of this view.

I see less significance in using the Capability Approach in order to validate the respect to children's rights, and rather suggest utilising it in a more narrow way, focusing on the implications of using the Capability Approach in the context of the child's right to development. Biggeri et al take a similar, more practical, approach, suggesting that 'human rights can be used as the main argument for defending a list of relevant capabilities for children', ${ }^{81}$ and that the Capability Approach 'can become a framework for normative evaluation and policy implementation. Therefore, it seems that the libertarian-inspired human rights approach and the Capability Approach can dialogue and complement each other quite well. ${ }^{\prime 2}$ Taking this idea forward, they suggest a concrete mode of operation:

in the case of children, on the one hand human rights can be used as the main argument for defending a list of relevant capabilities for children, and on the other the Capability Approach can become a framework for normative evaluation and policy implementation. ${ }^{83}$

I will return to this point in detail in the next section. First, I will discuss how the Capability Approach can reconceptualise children's development, in the context of the child's right to development.

81) Biggeri, M. et al, 'Children's Agency and the Capability Approach: A Conceptual Framework', in Biggeri, M. et al (eds) Children and the Capability Approach, supra n. 4, 22-45, 39-40.

82) Ibid.

83) Ibid. 


\section{Reconceptualising 'Children's Development'}

Applying the Capability Approach's conception of human development when interpreting the child's legal right to development can lead to three necessary changes: expanding the meaning of children's development beyond its current psycho-social meaning; enabling the development of a practical and concrete means of implementation; enhance the respect for children's agency and their right to participation.

The first contribution of the Capability Approach to the analysis of children's development and the child's right to development is to expand the meaning of the term 'children's development' beyond its current interpretation. It enables to diversify the meaning of this term and to stop seeing developmental psychology, which is the current dominant framework, as the only conceptual framework that should inform the interpretation of this term. Diversifying the meaning of children's development will inevitably lead to the rethinking of the concept of childhood. The reason is that the theoretical coherence of the current 'human becomings' will be undermined if 'children's development' does not only mean growing up.

The second contribution derives from the above-suggested change. I suggest using the terminology of capabilities to concretise 'children's development'. While Sen does not define the types of capabilities a person needs in order to be free, Polly Vizard claims that despite this reservation, international human rights law can help to generate 'a minimal list of central and basic capabilities with universal coverage'. ${ }^{4}$ According to Biggeri and Mehrotra, the Capability Approach is a 'framework for normative evaluation and policy implementation, ${ }^{85}$ and it provides normative and positive grounds for promoting these capabilities in children. Similarly, Nussbaum suggests a list of ten capabilities that she qualifies as concrete, universal, inseparable and essential to the realisation of human development. The ten capabilities are: life, bodily health, bodily integrity, sense, imagination and thought, emotions, practical reason, affiliation, other species and play and control over one's environment. ${ }^{86}$ Although Nussbaum considers these as the minimum universal capabilities that are necessary for us to be free, she admits that this list is slightly ambiguous, so individual societies can elaborate and interpret it differently,

84) Vizard, P., 'Specifying and Justifying a Basic Capability Set: Should the International Human Rights Framework be Given a More Direct Role?', Oxford Development Studies 35 (2007): 225-250, 235 .

85) Biggeri, B., et al, 'Children's Agency and the Capability Approach: A Conceptual Framework', in Children and the Capability Approach, supra n. 4, 39-40.

86) Nussbaum, Creating Capabilities - The Human Development Approach, supra n. 44, 33-34. 
according to their own traditions and histories. ${ }^{87}$ According to Vizard, these ten capabilities can be seen as grounds for a human rights based capability framework, ${ }^{88}$ mainly because they resemble the basic universal rights that are protected by the Universal Declaration of Human Rights and the 1966 Covenants as universal human rights. ${ }^{89}$

This list of capabilities can be seen as relevant for children for two reasons. First, it meets children's needs and arguably cannot be challenged on the basis of a pre-requirement for capacities. Second, following Vizard's observation, many of these capabilities are defined as children's rights by the Convention (which protects the child's right to life, health, bodily integrity, affiliations and play in Articles 6, 24, 19, 7, 8, 9, 11 and 31, respectively), so these rights, or children's entitlement to these capabilities, have universal acceptance (if only due to the near-universal ratification of the Convention). Therefore, taking the Capability Approach's perspective, these rights can be understood as necessary to the realisation of the child's right to development. Moreover, this list of capabilities also resembles the UNCRC's approach to the support of children's development. ${ }^{90}$ However, in the context of the Capability Approach, these capabilities - and the rights they resemble - serve a different purpose. These capabilities and corresponding rights support the child's freedom, whilst the Committee takes these rights as means to enable the child to become an adult.

A key problem with this list is that, like the Capability Approach in general, it was not created with children in mind. Biggeri and Mehrotra therefore suggest a different list, which they claim has more relevance to children. Their list includes 14 capabilities: life and physical health; love and care; mental wellbeing; bodily integrity and safety; social relations; participation; education; freedom from economic and non-economic exploitation; shelter and environment; leisure activities; respect; religion and identity; time autonomy; and mobility. ${ }^{91}$ Similar to Nussbaum's list, nine of the capabilities in this list can be named as children's rights under the Convention (Articles 6, 24, 12, 28, 29, 32, $27,31,14,30,7$ and 8 , respectively). The remaining capabilities, such as love and care, social relations and respect, are not considered human rights. ${ }^{92}$

87) Nussbaum, Ibid, 40. See Robeyns' claim that such a list should be rejected since it narrows down Sen's approach: I. Robeyns, 'An Unworkable Idea or a Promising Alternative? Sen's Capability Approach Re-examined' (1993) Center of Economic Discussion on Paper oo.30. University of Leuven, Mimeo.

88) Vizard, supra n. 84, 234-235.

89) Ibid.

90) Peleg, supra n. 2.

91) Biggeri, M. and S. Mehrotra, 'Child Poverty as Capability Deprivation: How to Choose Domains of Child Well-being and Poverty', in Children and the Capability Approach, supra n. 4, 51. 92) Though it was suggested that children do have the right to be loved, and the right to 'time autonomy'. See Korczak, J., 'How to Love a Child' in Selected works of Janusz Korczak. Wolins, M., ed. (Washington D.C: National Science Foundation, 1967) 355-356. 
By employing the Capability Approach's terminology, it can be argued that realising these rights provides the necessary capabilities for the child to be free. In practice, protecting these rights of children will serve dual purposes: protecting these rights themselves, and protecting all these rights simultaneously and constantly so every child has an equal opportunity to be free. For the children who live in any of the 193 states that signed and ratified the Convention, there is a source of obligation in international human rights law that obliges the different duty bearers to promote their capabilities and thus promote their human development. More specifically, the commitment of states parties is to promote these capabilities to 'the maximum extent possible. ${ }^{93}$

The third contribution of the Capability Approach is enhanced respect for the agency of individual children and children as a collective, and for children's right to participation. The Capability Approach's framework enables to emphasise the particular attention that should be given to the child's right to participate in shaping her own future. If children articulate their views concerning their own freedom, it will ease the tension between the two distinct conceptions of childhood - 'human becomings' and 'human beings'. Children should participate in the creation of a new interpretation of the right to development, and contribute their own opinions on the subject. They should also be part of the process of realising the right to development in practice, including in the process of developing implementation tools and practices (for example, development policies and programmes, and drafting new legislation on the subject). Flavio Comim claims that in the context of the Capability Approach, children usually 'are not consulted in the meaning of an active actor in society, ${ }^{\prime 4}$ though this sort of treatment ignores the fact that 'children would probably define the meaning of being an active actor or citizen differently' ${ }^{95}$ While Comim flags up this latter point as a potential argument against realising children's participation, this argument is in fact an excellent reason why children should participate. Their unique point of view about their own development is the reason for giving them a voice, rather than a reason to continue silencing them. Adopting the view that children, even toddlers, ${ }^{96}$ can and should express their preferences enables us to overcome one of the main barriers for implementing the Capability Approach in analysing the child's right to development. Children should play an active role in realising their self-determination, and express their preference about their own future. It seems that Saito is alarmed by this sort of suggestion, and therefore warns us that,

93) Article 6(2) of the UNCRC.

94) Comim et al, supra n. 4, 7 .

95) Ibid.

96) See Alderson, supra n. 32. 
giving temporary freedom to a child does not always mean that the child will have freedom in future, and similarly, restricting the temporary freedom of a child may well expend the freedom that the child will have in the future. We, therefore, have to consider the freedom for a child in a lifelong perspective. ${ }^{97}$

This concern for the child's future is well placed. However, one should not easily dismiss or undermine the value of the child's life in the present, and its manifestation in the right to participation. This strong preference for safeguarding the child's future undermines the recognition of children as rights holders, depriving them of agency and voice. This preference is based on an assumption that sacrificing children's freedom now will lead to a greater freedom in the future, once the child becomes an adult. Dixon and Nussbaum make a similar claim as they argue that 'we ought to support capabilities that will best promote a long-term future of full capabilities'. ${ }^{98}$ But ensuring freedoms in the future should not justify denying all freedoms in the present; rather, the contrary is true. Arguably, ensuring freedoms in the present will enable children to fulfil their potential and pursue lives worth living in the future. For this reason, children's voices and opinions should not be silenced or dismissed, but rather amplified.

I do not argue that care for the child's future should be overlooked when caring for children's development or for children's right to development. However, ensuring that the child will become an adult should also not be the only prism through which children's lives and development are perceived. We should care for children's life at the present time, and realise that children's futures include not only their adulthood, but also their childhood and their future while still being children. The 'future' of a one-month-old baby includes more than 17 years of life before she becomes an adult. ${ }^{99}$ Maybe even more importantly, in the 17 years during which this one-month-old child is living, she is experiencing the world and exercising agency, and should have all of her human rights protected, including her right to development.

\section{Conclusion}

The article suggests using the Capability Approach as a normative framework to analyse the child's right to development. Children, like adults, should be able to live lives worth living during their entire life span, including their time as children. The point of departure when interpreting the right to development

97) Saito, Supra n. 64, 26.

98) Dixon and Nussbaum, supra n. 6, 555 .

99) According to Article 1 of the Convention, unless an earlier age of majority applies. 
of children should be conceptualising children as active agents in shaping their own life, and respecting that they value different functions and have different capabilities from adults. Incorporating the Capability Approach's understanding of development in the context of the child's right to development can help expand the meanings of 'development' beyond its current psycho-social conception, and the child's right to development beyond its current understanding as the child's right to become an adult. The Capability Approach also suggests how the idea of 'human development' could be realised in practice, delineating what the necessary capabilities are. Children's agency deserves more respect than it currently gets, and such a change will shift the attention from questions of competence and welfare to those of human rights. It will enable to articulate the child's right to development as a distinct and concrete human right - the child will be seen to be entitled to grow, not only as in need of growing.

Another implication of respecting children's agency will be to respect children's right to participation, which symbolises children's ability - and right - to make sense of the world around them. ${ }^{100}$ Such a connection between children's development and their right to participation has yet to be made. Ignoring children's views in the context of their development perpetuates the image of children as passive subjects, whose sole purpose in life is to sit still and grow up. Children's participation also reflects, and promotes, the understanding of 'development' as an emancipatory process, which is the contribution of the Capability Approach to our analysis. The manifestation of the right to development as an emancipatory right and giving children a voice in this process requires a social and cultural transformation. ${ }^{101}$ Such a change includes the creation of a 'political space in which children are empowered to express their own distinctive and submerged point of view'. ${ }^{102}$ It will enable children, as a marginalised group, to express their own perspectives ${ }^{103}$ about their own development. Nonetheless, respecting children's right to participation does not mean that children will dictate the course of their childhood and future adulthood, not least because no one, child and adult alike, has a free standing in society. Children's participation does not mandate that children should be the only decision makers.

\footnotetext{
100) Lansdown, G., 'International Developments in Children's Participation: Lessons and Challenges' in Children, Young People and Social Inclusion. Tisdall, K. et al, eds. (Bristol: The Policy Press, 2006) 139-155.

101) Lund, R.,'At the Interface of Development Studies and Child Research: Rethinking Participating Child', Children's Geographies 5 (2007): 131-148.

102) Wall, supra n. 69, 92.

103) Thomas, N., 'Towards a Theory of Children's Participation', International Journal of Children's Rights 15 (2007): 199-218, 210.
} 
The article examined two lists of capabilities, with only one of them formulated explicitly with the intention to meet children's needs. These lists show that 'children's development' can be translated into human rights terms. However, a more contextualised list should be further developed in order to meet the needs and rights of different children in different circumstances. The suggested capabilities can later be articulated in human rights terms, using the universal acceptance of the Convention as a positive source. 